\title{
Immunopharmacology of Post-Myocardial Infarction and Heart Failure Medications
}

\author{
Mona Panahi ${ }^{1}$, Nimai Vadgama ${ }^{1}$, Mathun Kuganesan ${ }^{2}$, Fu Siong $\mathrm{Ng}^{1}$ and Susanne Sattler ${ }^{1, *} \mathbb{E}$ \\ 1 National Heart and Lung Institute, Imperial College London, London W12 0NN, UK; \\ mp4213@ic.ac.uk (M.P.); nv412@imperial.ac.uk (N.V.); f.ng@imperial.ac.uk (F.S.N.) \\ 2 University College London Medical School, University College London, London WC1E 6BT, UK; \\ mathun.kuganesan.17@ucl.ac.uk \\ * Correspondence: s.sattler@imperial.ac.uk
}

Received: 7 October 2018; Accepted: 29 October 2018; Published: 31 October 2018

\begin{abstract}
The immune system responds to acute tissue damage after myocardial infarction (MI) and orchestrates healing and recovery of the heart. However, excessive inflammation may lead to additional tissue damage and fibrosis and exacerbate subsequent functional impairment, leading to heart failure. The appreciation of the immune system as a crucial factor after MI has led to a surge of clinical trials investigating the potential benefits of immunomodulatory agents previously used in hyper-inflammatory conditions, such as autoimmune disease. While the major goal of routine post-MI pharmacotherapy is to support heart function by ensuring appropriate blood pressure and cardiac output to meet the demands of the body, several drug classes also affect a range of immunological pathways and modulate the post-MI immune response, which is crucial to take into account when designing future immunomodulatory trials. This review outlines how routine post-MI pharmacotherapy affects the immune response and may thus influence post-MI outcomes and development towards heart failure. Current key drug classes are discussed, including platelet inhibitors, statins, $\beta$-blockers, and renin-angiotensin-aldosterone inhibitors.
\end{abstract}

Keywords: myocardial infarction; heart failure; immunopharmacology; immunomodulation

\section{Introduction}

Heart failure (HF) defines the inability of the heart to meet the metabolic demands of the body and is a common consequence of myocardial infarction (MI). A recent study shows that $62.7 \%$ of patients with a hospital diagnosis of acute MI (AMI) developed HF in the following six years [1]. Local hypoxia after MI causes cardiomyocyte death and the immune system is recruited to remove necrotic debris and initiate scar formation [2]. Severe tissue damage may, however, cause a strong inflammatory response and result in excessive fibrosis, ongoing immune autoreactivity and adverse remodeling towards HF [3]. Preclinical and clinical agents targeting immunological pathways have been explored for post-MI benefits and the most promising candidates include inhibitors of early inflammatory mediators and pro-inflammatory cytokines. In a recent systematic review, we provide a thorough overview of established and novel immunomodulatory treatments post-MI and during HF and show that, despite promising outcomes in selected trials, heterogeneous patient populations and inconsistent trial design complicate analysis. A final conclusion about the true clinical benefit of these novel agents is therefore still lacking [4].

Importantly, standard drugs currently used in the post-MI therapeutic regimen also affect the immune system [5] (Figure 1; Table 1). This needs to be considered carefully when designing future immunomodulatory therapies, and it is feasible that immunomodulation may in fact contribute to the cardioprotective effects of current post-MI therapy. 
Here we discuss the immunological effects of routinely prescribed post-MI drugs, including platelet inhibitors, statins, $\beta$-blockers, and drugs targeting the renin-angiotensin-aldosterone system, including angiotensin converting enzyme (ACE) inhibitors, angiotensin receptor blockers, angiotensin receptor-neprilysin inhibitors, and aldosterone antagonists. We illustrate that potential interactions of existing and emerging immunomodulatory interventions with routine pharmacotherapy should be considered when designing patient therapeutic regimens.

Table 1. Post-myocardial-infarction (MI) and anti-heart-failure drugs and their immunomodulatory properties.

\begin{tabular}{|c|c|c|c|}
\hline & Drug Class & Example & Reported Immunological Effect \\
\hline \multirow{3}{*}{ Platelet inhibitor } & $\begin{array}{l}\text { Cyclooxygenase enzyme } \\
\text { inhibitors }\end{array}$ & Aspirin & $\begin{array}{l}\text { Decrease ROS formation [6] } \\
\text { Decrease leukocyte activation [6] } \\
\text { Decrease hs-CRP [7] } \\
\text { Decrease IL-6 [7] }\end{array}$ \\
\hline & $\mathrm{P} 2 \mathrm{Y}_{12}$ inhibitors & $\begin{array}{l}\text { Clopidogrel } \\
\text { Prasugrel } \\
\text { Ticagrelor }\end{array}$ & $\begin{array}{l}\text { Decrease hs-CRP [8] } \\
\text { Decrease platelet degranulation [6] } \\
\text { Decrease pro-inflammatory cytokines [6] } \\
\text { Decrease leukocyte activation [6] }\end{array}$ \\
\hline & GP IIb/IIIa inhibitors & Tirofiban & Decrease CRP levels [9] \\
\hline Statins & $\begin{array}{l}\text { HMG-CoA reductase and } \\
\text { intracellular GTPase inhibitors }\end{array}$ & $\begin{array}{l}\text { Atorvastatin } \\
\text { Rosuvastatin } \\
\text { Simvastatin }\end{array}$ & $\begin{array}{l}\text { Decrease T cell activation [10-13] } \\
\text { Increase FoxP3 in Treg cells [14-16] } \\
\text { Decrease IL-2 and TNF- } \alpha[17]\end{array}$ \\
\hline \multirow{3}{*}{$\beta$-blockers } & Selective $\beta 1$-blockers & $\begin{array}{l}\text { Bisoprolol } \\
\text { Nebivolol } \\
\text { Metoprolol }\end{array}$ & $\begin{array}{l}\text { Decrease TNF- } \alpha \text { and restore cytokine } \\
\text { network in DCM [18] } \\
\text { Decrease TNF- } \alpha \text {, IL-6, IL-10, sIL-2R, MCP-1, } \\
\text { IL-18 in CHF [19] } \\
\text { Decrease statin-mediated CRP decrease [20] }\end{array}$ \\
\hline & Nonselective $\beta$-blockers & Propranolol & $\begin{array}{l}\text { Decrease statin-mediated CRP decrease [20] } \\
\text { Increases IL-1 } \beta \text { and IL-6 } 6 \mathrm{~h} \text { after MI [21] } \\
\text { Increase NK cell activity [22] }\end{array}$ \\
\hline & $\beta 1-\beta 2-\alpha$-blockers & Carvedilol & $\begin{array}{l}\text { Decrease HLA-DR }{ }^{+} \text {and cytotoxic T-cell } \\
\text { activation [23] } \\
\text { Decrease ROS production [24] } \\
\text { Decrease CCL2 [25] }\end{array}$ \\
\hline \multirow{4}{*}{$\begin{array}{l}\text { Drugs targeting } \\
\text { the RAAS system }\end{array}$} & $\begin{array}{l}\text { Angiotensin converting } \\
\text { enzyme inhibitors }\end{array}$ & $\begin{array}{l}\text { Captopril } \\
\text { Enalapril } \\
\text { Ramipril }\end{array}$ & $\begin{array}{l}\text { Decrease TNF- } \alpha \text { and MCP- } 1[26,27] \\
\text { Decrease T cell activation }[26,27]\end{array}$ \\
\hline & Angiotensin receptor blockers & $\begin{array}{l}\text { Azilsartan } \\
\text { Candesartan } \\
\text { Losartan }\end{array}$ & $\begin{array}{l}\text { Decrease IL-6, TNF- } \alpha \text { and IL-1 } \beta \text { [28-31] } \\
\text { Decrease oxidative stress [31] } \\
\text { Decrease MCP-1 expression [31,32] } \\
\text { Increase IL-10 levels [33] }\end{array}$ \\
\hline & $\begin{array}{l}\text { Angiotensin } \\
\text { receptor-neprilysin inhibitors }\end{array}$ & $\begin{array}{c}\text { Entresto } \\
\text { (Sacubitril/Valsartan) }\end{array}$ & $\begin{array}{l}\text { Decrease IL-6 and IL-1 } \beta \text { [34] } \\
\text { Decrease collagen deposition [34] }\end{array}$ \\
\hline & Aldosterone antagonists & $\begin{array}{c}\text { Eplerenone } \\
\text { Spironolactone }\end{array}$ & $\begin{array}{l}\text { Decrease PAI-1 levels [35] } \\
\text { Decrease collagen deposition [36] }\end{array}$ \\
\hline
\end{tabular}

ROS, reactive oxidative species; hs-CRP, high sensitivity C-reactive protein; CRP, C-reactive protein; IL, interleukin; TNF- $\alpha$, tumour necrosis factor- $\alpha$; FoxP3, forkhead box P3; Treg, T regulatory cell; DCM, dilated cardiomyopathy; NK, natural killer cell; CCL2, chemokine ligand 2; HLA-DR, human leukocyte antigen-DR isotype; MCP, monocyte chemoattractant protein; PAI-1, plasminogen activator inhibitor-1; HMG-CoA, $\beta$-Hydroxy $\beta$-methylglutaryl-coenzyme A. 


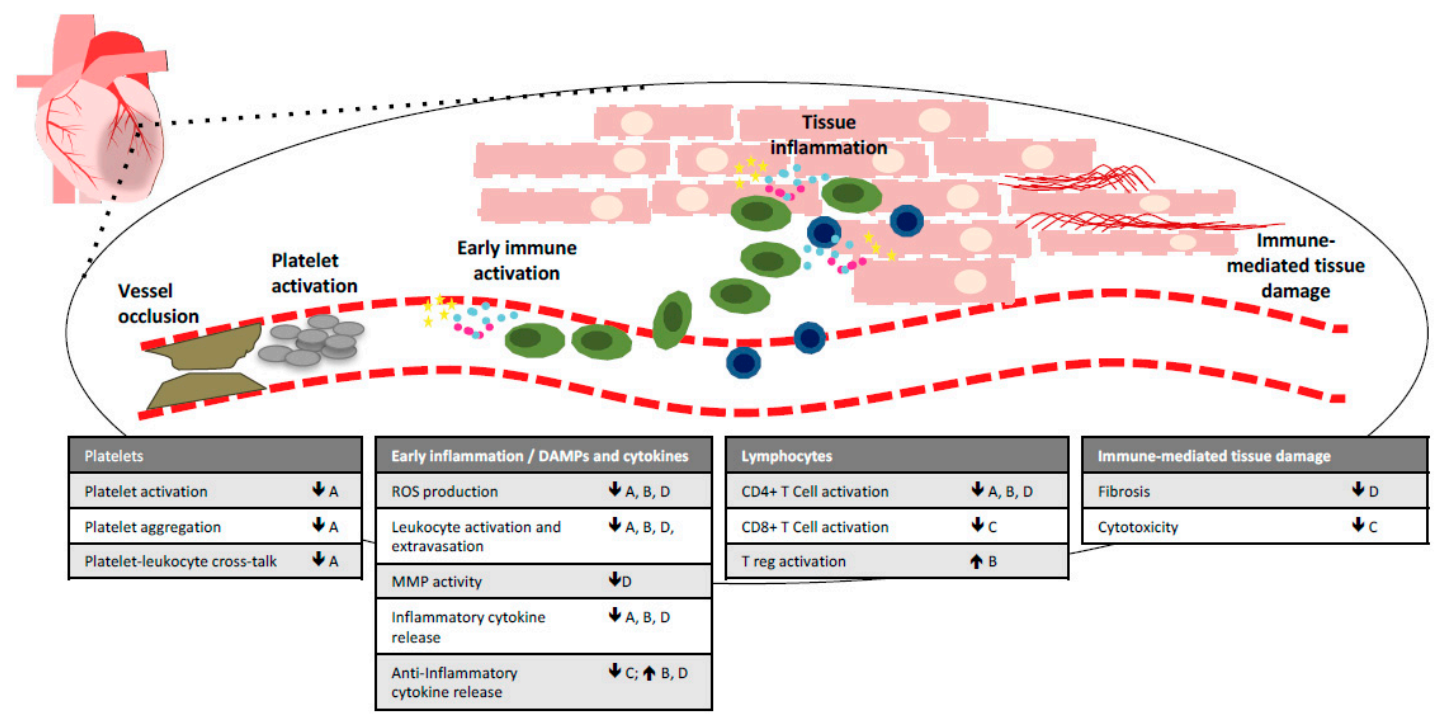

A: Platelet Inhibitors, B: Statins; C: $\beta$-Blockers; D: Renin-Angiotensin-Aldosterone System Inhibitors

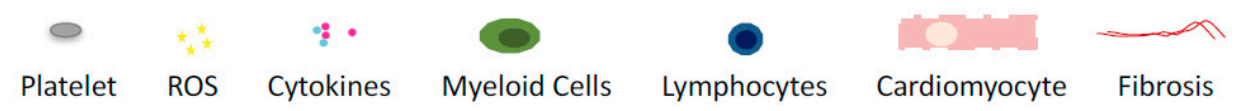

Figure 1. Immunomopharmacology of commonly used post-MI and heart failure drugs. The immune system is involved in all post-MI processes, including platelet activation immediately after vessel occlusion, early immune activation leading to leukocyte extravasation into the heart, and immune-mediated tissue damage. Currently used post-MI drugs with immunomodulatory effects include platelet inhibitors (A), statins (B), beta-blockers (C), and drugs targeting the renin-angiotensin-aldosterone system (D), including angiotensin converting enzyme (ACE) inhibitors, angiotensin receptor blockers, angiotensin receptor-neprilysin inhibitors and aldosterone antagonists. DAMPs; danger associated molecular patterns, ROS; reactive oxygen species, MMP; metalloproteinase. $\downarrow$ decrease, $\uparrow$ increase.

\section{Platelet Inhibitors}

Antithrombotic drugs are administered post-MI to reduce the risk of thrombus formation, thus decreasing the risk of MI reoccurrence [37]. Pharmacological agents used to achieve this are antiplatelet drugs, anticoagulants, and thrombolytic drugs, with platelet inhibitors being the most prominent antithrombotic drug class in routine long-term use for secondary prevention of MI.

Platelet and monocyte counts increase with MI severity and platelets continue to be activated in HF, irrespective of therapy [38]. However, platelets have important roles beyond haemostasis. They interact with the endothelium and leukocytes to promote activation, adhesion, and extravasation of monocytes, neutrophils, and lymphocytes and thereby contribute not only to thrombotic occlusion and microembolisation of coronary arteries, but also to inflammation [38]. Cyclo-oxygenase (COX) inhibitors (e.g., aspirin) and adenosine diphosphate receptor ( $\mathrm{P}^{2} \mathrm{Y}_{12}$ ) antagonists (e.g., clopidogrel, ticagrelor, prasugrel) are routinely prescribed platelet inhibitors post-MI [39].

\subsection{COX Inhibitors}

COX inhibition irreversibly blocks platelet aggregation [40]. The most prominent COX inhibitor, aspirin, has been shown to block reactive oxygen species (ROS) formation and platelet and leukocyte activation [6]. Monitoring inflammatory markers of 310 AMI patients in the warfarin-aspirin re-infarction study (WARIS-II, 2003) showed that $160 \mathrm{mg} /$ day of aspirin reduced high-sensitivity C-reactive protein (hs-CRP) at both three months and four years and Interleukin (IL)-6 was also significantly reduced at a four-year follow-up, compared to warfarin alone [7]. 


\section{2. $P 2 Y_{12}$ Antagonists}

$\mathrm{P}_{2} \mathrm{Y}_{12}$ receptors play a primary role in haemostasis and platelet aggregation upon adenosine diphosphate (ADP) binding [41]. Examples of $\mathrm{P}_{2} \mathrm{Y}_{12}$ inhibitors include clopidogrel, ticagrelor, and prasugrel, which are routinely prescribed post-MI [37]. P2 $\mathrm{Y}_{12}$ inhibitors can suppress degranulation, platelet-leukocyte aggregate formation, and expression of pro-inflammatory cytokines [6]. In a clinical trial with 120 patients undergoing percutaneous coronary intervention (PCI), both prasugrel and clopidogrel significantly reduced hs-CRP levels [8].

\subsection{Glycoprotein (GP) IIb/IIIa Inhibitor}

The platelet receptor GPIIb/IIIa binds fibrinogen, thus bridging adjacent platelets for aggregation [42]. A GPIIb/IIIa inhibitor, tirofiban, has been shown in a small study by Ercan et al. (2004) to significantly reduce C-reactive protein (CRP) in non-ST elevation MI (NSTEMI) patients when prescribed for $48 \mathrm{~h}$ following MI [9].

Due to the various pro-inflammatory effects of activated platelets, their inhibition also suppresses inflammatory chemokine, cytokine, and adhesion molecule expression. Although not their intended primary function, platelet inhibitors may therefore possess potent anti-inflammatory effects.

\section{Statins}

Statins inhibit the liver enzyme $\beta$-hydroxy $\beta$-methylglutaryl-coenzyme A (HMG-CoA) reductase, which is involved in the production of low-density lipoprotein-cholesterol (LDL-C). Reducing LDL-C levels is anticipated to reduce atherosclerotic plaque formation and protect from re-infarction [43]. Statins are the most commonly prescribed lipid-lowering agent worldwide [44]. However, statins exert additional advantageous cardiovascular effects, which are independent of their lipid-lowering effects, including improvement of endothelial function, antithrombotic effects, antioxidant effects, antiproliferative effects on smooth muscle cells, and anti-inflammatory effects $[45,46]$. Previous meta-analyses have shown that the use of statins during preloading in patients undergoing PCI significantly reduced the rates of periprocedural MI and Major Adverse Cardiovascular events (MACE) [47,48]. In non-ischaemic HF, atorvastatin significantly improves patients' left ventricular ejection fraction (LVEF), which is thought to be due to attenuation of adverse left ventricular (LV) modelling [49].

Recent studies have suggested that their favourable clinical outcomes could be in part due to their immunomodulatory properties affecting immune cell proliferation and migration [50]. Statins modulate the $\mathrm{T}$ cell repertoire by blocking antigen-specific $\mathrm{T}$ cell activation and inducing an anti-inflammatory and regulatory $\mathrm{T}$ (Treg) cell phenotype. Porcine studies reported a 25-fold reduction in major histocompatibility (MHC) class II molecule expression on vascular endothelial cells following statin administration [10]. Alongside MHC class II, reduced expression of MHC class I, and co-stimulatory molecules CD28 and CD40 have been described [11]. MHC class II is found constitutively on antigen-presenting cells and is essential for antigen-dependent $\mathrm{T}$ cell activation. Multiple cell types, including endothelial cells, monocytes, and macrophages, can be stimulated by interferon (IFN) $-\gamma$ to express MHC class II molecules on their cell surface to activate the adaptive immune system, but statins can intercept this process [12]. Statins further block intracellular GTPases, which impairs protein antigen uptake and subsequently dampens $\mathrm{T}$ cell activation [13].

Statins also directly promote immune tolerance by increasing the expression of transcription factor forkhead box P3 (FoxP3) in Treg cells, along with immune regulatory cytokines IL-10 and tumour growth factor- $\beta$ (TGF- $\beta$ ) in atherosclerotic plaques [14]. Treg cell migration and differentiation via the C-C motif ligant-1 (CCL1) chemokine is influenced by statin administration [15] and, clinically, an increase in FoxP3 mRNA levels has been observed in male patients following one month of statin use [16]. 
Simvastatin administered to ST-elevation MI (STEMI) patients reduced the levels of the inflammatory cytokines IL-2 and tumour necrosis factor (TNF)- $\alpha$ in a dose-dependent manner, with a significant but transient drop in CRP in the first week, compared to placebo treatments. Although CRP returned to normal by day 30 , the flow-mediated dilation of the brachial artery was proportional to the initial statin dose [17]. This study indicates that the timing and dose of statin therapy influence the inflammatory and endothelial responses following MI.

Considering the detrimental effect of post-MI adaptive immune-autoreactivity and beneficial effect of Treg cells in heart regeneration [51], it is feasible that these striking effects on the adaptive immune system may play an important role in the observed clinical effects of statins in slowing the post-MI progression to heart failure.

\section{4. $\beta$-Blockers}

$\beta$-Blockers are used post-MI to reduce heart rate and blood pressure (BP). They constitute a heterogeneous group of drugs blocking the adrenoreceptors of the sympathetic nervous system. They can be selective inhibitors of $\beta 1$-adrenoreceptors (e.g., metoprolol, bisoprolol, low concentrations of nebivolol), nonselective blockers of both $\beta 1$ - and $\beta 2$-adrenoreceptors (e.g., propranolol, high concentrations of nebivolol), and a third generation of nonselective $\beta$-blockers $/ \alpha 1$ blockers (e.g., carvedilol). Nebivolol, atenolol, and bisoprolol are the main treatment options after acute coronary syndrome (ACS), largely due to their superior cardioselectivity when compared to other $\beta$-blockers [52]. $\beta$-Blockers have infarct-reducing properties, improve cardiac function, and can help to prevent future infarcts [53]. Their immunological effects vary and may prove beneficial or detrimental, depending on the exact setting.

\subsection{Selective $\beta 1$ Antagonists}

Bisoprolol reduces circulating TNF- $\alpha$ levels and helps to restore the dysregulated cytokine network in dilated cardiomyopathy (DCM) patients [18]. Similarly, metoprolol lowers plasma levels of TNF- $\alpha$, IL-6, IL-10, soluble IL-2 receptor (sIL-2R), monocyte chemoattractant peptide-1 (MCP-1), and IL-8 in chronic HF (CHF) patients [19]. Post-MI, however, metoprolol may in fact attenuate the anti-inflammatory effects of statins, as assessed by CRP level [20]. Metoprolol is available in two formulations, immediate-release metoprolol tartrate (MT) and slow-release metoprolol succinate (MS), of which only MS is recommended for the treatment of heart failure [54].

\subsection{Non-Selective $\beta$-Blockers}

Propranolol strongly upregulated IL- $1 \beta$ and IL-6 gene expression in the myocardium $6 \mathrm{~h}$ after $\mathrm{MI}$ in a rat model [21]. Similar to metoprolol, propranolol may also attenuate the anti-inflammatory effects of statins [20]. However, it is noted that propranolol is thought to increase the activity of NK cells [22], which may modulate the inflammatory milieu in a positive manner [55].

\subsection{Nonselective $\beta$-Blockers/ $\alpha 1$ Blockers}

Carvedilol reduces the levels of HLA-DR positive lymphocytes and cytotoxic T cells in the blood of CHF patients [23] and is therefore of particular interest. The presence of these cells has been implicated in myocardial dysfunction, cytotoxicity, and increased risk of severe post-MI HF [56]. Carvedilol has also been shown to decrease the production of ROS, such as $\mathrm{H}_{2} \mathrm{O}_{2}$, which is responsible for driving calcium overload in HF [24]. In a study on experimental infection with Trypanosoma cruzi, carvedilol decreased CCL2 levels and increased the levels of the anti-inflammatory cytokine IL-10, resulting in decreased inflammatory infiltration in cardiac muscle [25].

Depending on the drug type and timing of administration, $\beta$-blockers may thus have strikingly distinct immunological consequences. They might interfere with the resolution of inflammation in AMI, yet the blocking of adaptive autoreactivity during CHF may be a significant positive contributor to the beneficial effects of $\beta$-blockers in these patients. 


\section{Drugs Targeting the Renin-Angiotensin-Aldosterone System}

The Renin-Angiotensin-Aldosterone System (RAAS) is involved in regulating BP, blood volume, and sodium concentration. In response to a BP drop, the kidneys release renin, which cleaves angiotensinogen into angiotensin I. The angiotensin converting enzyme (ACE) then converts angiotensin I into angiotensin II (ATII). ATII binds to $\mathrm{AT}_{1}$ receptors, causing systemic vasoconstriction, resulting in increased systemic arterial pressure and restoration of BP. ATII thus stimulates cardiac hypertrophy and myocardial fibrosis [57]. Notably, ATII signalling also increases the release of inflammatory cytokines TNF- $\alpha$ and MCP-1 and upregulates T cells activation [26,27].

\subsection{ACE Inhibitors (ACEi)}

ACE inhibitors (ACEi) reduce plasma ATII concentrations and ATII-mediated vasoconstriction. This reduces pre- and afterload on the heart and decreases the risk of heart failure [58]. Blocking the pro-inflammatory effects of ATII with ACEi might improve the inflammatory environment in the heart [59]. Murine studies demonstrate that the ACEi enalapril reduced ATII-dependent monocyte recruitment from the spleen into the myocardium and increased ejection fraction by $14 \%$ [60]. Enalapril following MI also resulted in a significant reduction in the plasma levels of MCP-1 [61], a potent monocyte chemotactic agent [62].

\subsection{Angiotensin II Type-1 Receptor Blockers (ARB)}

Angiotensin II type- 1 receptor blockers (ARB) block the $\mathrm{AT}_{1}$ receptor and similarly optimise cardiac output, and are often used when the side effects of ACEi cannot be tolerated [53]. ARB and ACEi have similar immunological effects, and clinical and preclinical studies have demonstrated that following MI, ARB reduce levels of pro-inflammatory cytokines IL-6 and TNF- $\alpha$, while enhancing anti-inflammatory cytokine production [28,29]. ARB-mediated reduction of MCP-1 expression results in fewer monocytes and macrophages infiltrating the damaged myocardium, limiting cardiac remodelling and fibrosis [32]. Furthermore, ARB decrease the degree of ischaemic injury, infarct size, cardiomyocyte damage, and blood flow impairment [28]. A clinical trial comparing ramipril (ACEi) and olmesartan (ARB) showed a consistent reduction in infarct size, macrophage infiltration, and associated IL- $1 \beta$ and IL-6 levels for both dugs. However, olmesartan improved physiological parameters to a greater extent [30]. ARB also improve vascular inflammation by reducing oxidative stress, MCP-1 levels, macrophage and monocyte infiltration, vessel wall NADPH, and TNF- $\alpha$ in perivascular fat [31], and increase IL-10 levels [33].

\subsection{Angiotensin Receptor-Neprilysin Inhibitors (ARNi)}

The neutral endopeptidase neprilysin catalyses the degradation of atrial and brain natriuretic peptides (ANP, BNP), bradykinin and ATII. Inhibition of neprilysin results in natriuretic and antiproliferative effects and vasodilation [63]. The most prominent ARNi is entresto, a combination of sacubitril (neprilysin inhibitor) and valsartan (ARB), which is used as an alternative to or alongside ACEi and ARB in patients with symptomatic chronic heart failure with low ejection fraction [64]. The European Society of Cardiology HF guidelines recommend sacubitril/valsartan as a replacement for an ACEi to further reduce the risk of HF hospitalisation and death in ambulatory patients with HF with reduced ejection fraction (EF) who remain symptomatic despite optimal treatment with an ACEi, a $\beta$-blocker, and a mineralocorticoid receptor antagonists (MRA) [65]. Entresto decreases aldosterone release, fibrosis, and ventricular hypertrophy [66].

In experimental AMI, entresto suppressed pro-inflammatory cytokines IL-1 $\beta$ and IL- 6 and extracellular matrix degradation by macrophages [34]. In diabetic mice with established heart failure, entresto reduced fibrosis by suppressing TGF- $\beta$ [67]. 


\subsection{Aldosterone Antagonists (AA)}

Aldosterone antagonists (AA) reduce sodium and fluid retention, thus lowering blood volume and preload on the heart [53]. They dampen the detrimental effects of high plasma aldosterone concentrations post-MI, including progressive myocardial fibrosis, increased plasminogen activator inhibitor-1 (PAI-1) concentration, and decreased noradrenaline uptake [35]. Medical intervention is time-dependent, with optimal outcomes when administered within seven days after infarct [68]. Spironolactone, a competitive MRA, blocks the aldosterone receptors present on endothelial cells and monocytes, thus suppressing the downstream inflammatory cascade, which would otherwise lead to myofibroblast differentiation, collagen deposition, and fibrosis [36].

Fortuitous blocking of pro-inflammatory factors in the RAAS, thus, has immunomodulatory effects and may contribute to improved post-MI outcomes after treatment.

\section{Conclusions and Future Perspectives}

Immunological interventions are increasingly becoming integrated into everyday medical practice in various settings and are a promising expanding area of science. However, we still have a long way to go until a new immunomodulatory drug is used clinically in post-MI pharmacotherapy. Considering immunopharmacology of routine drugs, as well as their possible synergistic or antagonistic effects, with new therapies is a first step towards improved patient care and future trial design.

Clinical trials specifically targeting the post-MI immune response: A great number of clinical trials have aimed at immunomodulation post-MI, ranging from broad immunosuppressive approaches using corticosteroids, methotrexate or cyclosporine A, to more refined approaches targeting specific pathways and factors, including ROS, complement, mast cells, leukocyte infiltration, inflammatory cytokines IL-1, TNF- $\alpha$ and IL-6, and the inhibition of adaptive B and T lymphocytes [4]. The most promising target to date is IL-1. IL-1 inhibitors, including anakinra and canakinumab, which were initially developed for use in systemic inflammatory conditions, such as rheumatoid arthritis, have recently been tested in patients following AMI and show a significant benefit in the secondary prevention of subsequent cardiac events $[69,70]$. However, despite an enormous amount of effort and resources invested in these immunomodulatory trials, practical challenges, dealing with a highly diverse patient population, and striking heterogeneity in trial design mean that firm evidence in support of immunomodulatory treatment is still missing.

Therapeutic window: The post-MI immune response is highly dynamic and the pre-MI and the periprocedural clinical situation during PCI affect the degree of cardiac damage and therefore long-term complications, including the development towards HF. Some of the drug classes mentioned above are also administered perioperatively in patients undergoing PCI.

Most prominently, antithrombotic agents, such as heparin and bivalrudin, are part of the acute pharmacological treatment regime of STEMI patients to restore blood flow. Heparin significantly reduced CRP levels when administered before reperfusion [71] and low-molecular-weight heparin (enoxaparin) significantly decreased IL-6 levels [72]. Bivalrudin, a direct thrombin inhibitor, is currently recommend by both EU and US guidelines for use during primary PCI instead of heparin plus platelet inhibitors [73]. Heparin has established anti-inflammatory effects [74], but studies on the immunological effects of bivalrudin are still missing.

Another example, administration of the $\beta$-blocker metoprolol before reperfusion in patients undergoing PCI for STEMI, resulted in improved LVEF at six months follow-up, and a reduced occurrence of the prespecified composite of death, heart failure admission, re-infarction, and malignant arrhythmias at a median follow-up of two years, therefore indicating a possible long-term benefit of periprocedural $\beta$-blockers [75]. Immunological factors were not measured in this trial and it is therefore unclear if immunomodulation plays a role in these effects.

However, it is important to appreciate that any treatment to improve and accelerate reperfusion during AMI will affect the ensuing inflammatory response and downstream development to HF, which does not allow conclusions about specific immunomodulatory effects in a periprocedural setting. 
New treatment strategies: The reality that despite potent post-MI pharmacotherapy, recurrent ischaemic events are common, drives the ongoing search for additional and better post-MI drugs. In particular, improved antithrombotic strategies seem warranted. Combinations of nonvitamin $\mathrm{K}$ antagonist oral anticoagulant (NOAC) with antiplatelet therapy have shown promising outcomes in large phase II and III randomised trials, suggesting that the use of NOAC in addition to standard antiplatelet therapy reduces the rate of recurrent ischaemic events. However, this comes at the price of increased risk for major bleeding [76].

Another recent addition to post-MI pharmacotherapy is ivabradine, a selective inhibitor of cardiac pacemaker cells in the sinus node of the right atrium, which controls the heart rate. Beyond its current use in treating stable angina [77], increasing evidence suggests ivabradine decreases cardiac structural remodelling and alleviates the risks of developing HF post-MI [78]. Immunological effects have been suggested by a study showing an increase in circulating numbers of myeloid dendritic cells (mDC) after six months of ivabradine treatment [78]. mDC negatively correlate with HF progression $[79,80]$. The same study showed a significant reduction in TNF- $\alpha$ concentrations [78]. A significant decrease in hsCRP levels was further recorded in patients treated with ivabradine for 30 days [81] which could be another plausible mechanism through which ivabradine reduces HF risk. In conclusion, despite a paucity of clinical trials, evidence suggests ivabradine has immunomodulatory effects.

Combination therapy: The immune response is a crucial player in post-MI restoration of tissue integrity. However, while immunomodulation may prevent ongoing damage, it is unlikely to replace tissue that has been lost already. Combining immunomodulation with regenerative therapies, such as biomaterial-based strategies or cell therapies aiming to replace damaged cardiomyocytes, seems the most promising future strategy [3]. Numerous studies have evaluated the effect of stem cell mobilisation, recruitment or transplantation into the myocardium [82,83]. While both fields are still in their infancy, once initial hurdles are overcome, the outlook for cardiac regeneration post-MI is promising.

Complications of immunotherapies: Potential side effects need to be carefully considered before the administration of immunosuppressive drugs post-MI. The immune system needs to be tightly regulated to ensure efficient responses against infections and cancers, while preventing autoreactivity. Suppressing the immune system post-MI may impact wound healing and regenerative processes, weaken defences against infectious diseases, and undermine the ability of the immune system to detect and destroy malignant growth early on. Chronic immunosuppressive treatment using methotrexate, cyclosporine or anti-TNF reagents is known to carry an increased risk of lymphoma, due to decreased immunosurveillance [84].

Funding: This work was supported by the British Heart Foundation (PG/16/93/32345 to S.S. and RG/16/3/32175 to F.S.N.).

Acknowledgments: We are grateful to Nadia Rosenthal, The Jackson Laboratories, US, for helpful discussion.

Conflicts of Interest: The authors declare no conflict of interest. The funding sponsors had no role in the design of the study; in the collection, analyses, or interpretation of data; in the writing of the manuscript, and in the decision to publish the results.

\section{References}

1. Torabi, A.; Cleland, J.G.F.; Khan, N.K.; Loh, P.H.; Clark, A.L.; Alamgir, F.; Caplin, J.L.; Rigby, A.S.; Goode, K. The timing of development and subsequent clinical course of heart failure after a myocardial infarction. Eur. Heart J. 2008, 29, 859-870. [CrossRef] [PubMed]

2. Frangogiannis, N.G. The inflammatory response in myocardial injury, repair, and remodelling. Nat. Rev. Cardiol. 2014, 11, 255-265. [CrossRef] [PubMed]

3. Sattler, S.; Fairchild, P.; Watt, F.M.; Rosenthal, N.; Harding, S.E. The adaptive immune response to cardiac injury-The true roadblock to effective regenerative therapies? npj Regen. Med. 2017, 2, 19. [CrossRef] [PubMed] 
4. Panahi, M.; Papanikolaou, A.; Torabi, A.; Zhang, J.-G.; Khan, H.; Vazir, A.; Hasham, M.; Cleland, J.G.F.; Rosenthal, N.; Harding, S.E.; et al. Immunomodulatory interventions in myocardial infarction and heart failure: A systematic review of clinical trials and meta-analysis of IL-1 inhibition. Cardiovasc. Res. 2018, 114, 1445-1461. [CrossRef] [PubMed]

5. Jugdutt, B.I. Pleiotropic effects of cardiac drugs on healing post-MI. The good, bad, and ugly. Heart Fail. Rev. 2008, 13, 439-452. [CrossRef] [PubMed]

6. Schrottmaier, W.C.; Kral, J.B.; Badrnya, S.; Assinger, A. Aspirin and P2Y 12 inhibitors in platelet-mediated activation of neutrophils and monocytes. Thromb. Haemost. 2015, 114, 478-789. [CrossRef] [PubMed]

7. Solheim, S.; Arnesen, H.; Eikvar, L.; Hurlen, M.; Seljeflot, I. Influence of aspirin on inflammatory markers in patients after acute myocardial infarction. Am. J. Cardiol. 2003, 92, 843-845. [CrossRef]

8. Hajsadeghi, S.; Chitsazan, M.; Chitsazan, M.; Salehi, N.; Amin, A.; Bidokhti, A.A.; Babaali, N.; Bordbar, A.; Hejrati, M.; Moghadami, S. Prasugrel Results in Higher Decrease in High-Sensitivity C-Reactive Protein Level in Patients Undergoing Percutaneous Coronary Intervention Comparing to Clopidogrel. Clin. Med. Insights Cardiol. 2016, 10, 149-155. [CrossRef] [PubMed]

9. Ercan, E.; Tengiz, I.; Duman, C.; Onbasili, O.A.; Baris, N. Effect of tirofiban on C-reactive protein in non-ST-elevation myocardial infarction. Am. Heart J. 2004, 147, 54-57. [CrossRef]

10. Geissler, I.; Collins, L.; Schofield, R.; Fabre, J.W. In Vivo Suppression of Major Histocompatibility Complex Class II Expression on Porcine Vascular Endothelial Cells by an HMG-CoA Reductase Inhibitor. Transplantation 2006, 81, 922-926. [CrossRef] [PubMed]

11. Kuipers, H.F.; Biesta, P.J.; Groothuis, T.A.; Neefjes, J.J.; Mommaas, A.M.; van den Elsen, P.J. Statins Affect Cell-Surface Expression of Major Histocompatibility Complex Class II Molecules by Disrupting Cholesterol-Containing Microdomains. Hum. Immunol. 2005, 66, 653-665. [CrossRef] [PubMed]

12. Kwak, B.; Mulhaupt, F.; Myit, S.; Mach, F. Statins as a newly recognized type of immunomodulator. J. Chem. Inf. Model. 2013, 53, 1689-1699. [CrossRef] [PubMed]

13. Ghittoni, R.; Napolitani, G.; Benati, D.; Uliveri, C.; Patrussi, L.; Laghi Pasini, F.; Lanzavecchia, A.; Baldari, C.T. Simvastatin inhibits the MHC class II pathway of antigen presentation by impairing Ras superfamily GTPases. Eur. J. Immunol. 2006, 36, 2885-2893. [CrossRef] [PubMed]

14. Lee, K.J.; Moon, J.Y.; Choi, H.K.; Kim, H.O.; Hur, G.Y.; Jung, K.H.; Lee, S.Y.; Kim, J.H.; Shin, C.; Shim, J.J.; et al. Immune regulatory effects of simvastatin on regulatory $\mathrm{T}$ cell-mediated tumour immune tolerance. Clin. Exp. Immunol. 2010, 161, 298-305. [CrossRef] [PubMed]

15. Mira, E.; León, B.; Barber, D.F.; Jiménez-Baranda, S.; Goya, I.; Almonacid, L.; Márquez, G.; Zaballos, A.; Martínez-A., C.; Stein, J.V.; et al. Statins Induce Regulatory T Cell Recruitment via a CCL1 Dependent Pathway. J. Immunol. 2008, 181, 3524-3534. [CrossRef] [PubMed]

16. Rodriguez-Perea, A.L.; Montoya, C.J.; Olek, S.; Chougnet, C.A.; Velilla, P.A. Statins increase the frequency of circulating CD4+ FOXP3+ regulatory T cells in healthy individuals. J. Immunol. Res. 2015, 2015, 1-8. [CrossRef] [PubMed]

17. Sposito, A.C.; Santos, S.N.; de Faria, E.C.; Abdalla, D.S.P.; da Silva, L.P.; Soares, A.A.S.; Japiassu, A.V.T.; Quinaglia e Silva, J.C.; Ramires, J.A.F.; Coelho, O.R. Timing and Dose of Statin Therapy Define Its Impact on Inflammatory and Endothelial Responses During Myocardial Infarction. Arterioscler. Thromb. Vasc. Biol. 2011, 31, 1240-1246. [CrossRef] [PubMed]

18. Ohtsuka, T.; Hamada, M.; Hiasa, G.; Sasaki, O.; Suzuki, M.; Hara, Y.; Shigematsu, Y.; Hiwada, K. Effect of beta-blockers on circulating levels of inflammatory and anti-inflammatory cytokines in patients with dilated cardiomyopathy. J. Am. Coll. Cardiol. 2001, 37, 412-417. [CrossRef]

19. Gullestad, L.; Ueland, T.; Brunsvig, A.; Kjekshus, J.; Simonsen, S.; Frøland, S.S.; Aukrust, P. Effect of metoprolol on cytokine levels in chronic heart failure-A substudy in the Metoprolol Controlled-Release Randomised Intervention Trial in Heart Failure (MERIT-HF). Am. Heart J. 2001, 141, 418-421. [CrossRef] [PubMed]

20. Quinaglia e Silva, J.C.; Munhoz, D.B.; Morato, T.N.; Gurgel, A.; Macedo, A.C.T.; Sever, P.; Sposito, A.C. Effect of beta blockers (metoprolol or propranolol) on effect of simvastatin in lowering C-reactive protein in acute myocardial infarction. Am. J. Cardiol. 2009, 103, 461-463. [CrossRef] [PubMed]

21. Deten, A.; Volz, H.C.; Holzl, A.; Briest, W.; Zimmer, H.-G. Effect of propranolol on cardiac cytokine expression after myocardial infarction in rats. Mol. Cell. Biochem. 2003, 251, 127-137. [CrossRef] [PubMed] 
22. Avraham, R.; Benish, M.; Inbar, S.; Bartal, I.; Rosenne, E.; Ben-Eliyahu, S. Synergism between immunostimulation and prevention of surgery-induced immune suppression: An approach to reduce post-operative tumor progression. Brain Behav. Immun. 2010, 24, 952-958. [CrossRef] [PubMed]

23. Shaw, S.M.; Coppinger, T.; Waywell, C.; Dunne, L.; Archer, L.D.; Critchley, W.R.; Yonan, N.; Fildes, J.E.; Williams, S.G. The effect of beta-blockers on the adaptive immune system in chronic heart failure. Cardiovasc. Ther. 2009, 27, 181-186. [CrossRef] [PubMed]

24. Kametani, R.; Miura, T.; Harada, N.; Shibuya, M.; Wang, R.; Tan, H.; Fukagawa, Y.; Kawamura, S.; Matsuzaki, M. Carvedilol inhibits mitochondrial oxygen consumption and superoxide production during calcium overload in isolated heart mitochondria. Circ. J. 2006, 70, 321-326. [CrossRef] [PubMed]

25. Horta, A.L.; Leite, A.L.J.; Paula Costa, G.; Figueiredo, V.P.; Talvani, A. Potential Role of Carvedilol in the Cardiac Immune Response Induced by Experimental Infection with Trypanosoma cruzi. Biomed Res. Int. 2017, 2017, 1-7. [CrossRef] [PubMed]

26. Kortekaas, K.E.; Meijer, C.A.; Hinnen, J.W.; Dalman, R.L.; Xu, B.; Hamming, J.F.; Lindeman, J.H. ACE inhibitors potently reduce vascular inflammation, results of an open proof-of-concept study in the abdominal aortic aneurysm. PLoS ONE 2014, 9, e111952. [CrossRef] [PubMed]

27. Kranzhöfer, R.; Browatzki, M.; Schmidt, J.; Kübler, W. Angiotensin II Activates the Proinflammatory Transcription Factor Nuclear Factor-kB in Human Monocytes. Biochem. Biophys. Res. Commun. 1999, 257, 826-828. [CrossRef] [PubMed]

28. Jugdutt, B.I.; Jelani, A.; Palaniyappan, A.; Idikio, H.; Uweira, R.E.; Menon, V.; Jugdutt, C.E. Aging-related early changes in markers of ventricular and matrix remodeling after reperfused st-segment elevation myocardial infarction in the canine model: Effect of early therapy with an angiotensin II type 1 receptor blocker. Circulation 2010, 122, 341-351. [CrossRef] [PubMed]

29. Clancy, P.; Koblar, S.A.; Golledge, J. Angiotensin receptor 1 blockade reduces secretion of inflammation associated cytokines from cultured human carotid atheroma and vascular cells in association with reduced extracellular signal regulated kinase expression and activation. Atherosclerosis 2014, 236, 108-115. [CrossRef] [PubMed]

30. Sandmann, S.; Li, J.; Fritzenkötter, C.; Spormann, J.; Tiede, K.; Fischer, J.W.; Unger, T. Differential effects of olmesartan and ramipril on inflammatory response after myocardial infarction in rats. Blood Press. 2006, 15, 116-128. [CrossRef] [PubMed]

31. Matsumoto, S.; Shimabukuro, M.; Fukuda, D.; Soeki, T.; Yamakawa, K.; Masuzaki, H.; Sata, M. Azilsartan, an angiotensin II type 1 receptor blocker, restores endothelial function by reducing vascular inflammation and by increasing the phosphorylation ratio $\operatorname{Ser}^{1177} / \mathrm{Thr}^{497}$ of endothelial nitric oxide synthase in diabetic mice. Cardiovasc. Diabetol. 2014, 13, 30. [CrossRef] [PubMed]

32. Nakano, Y.; Matoba, T.; Tokutome, M.; Funamoto, D.; Katsuki, S.; Ikeda, G.; Nagaoka, K.; Ishikita, A.; Nakano, K.; Koga, J.-I.; et al. Nanoparticle-Mediated Delivery of Irbesartan Induces Cardioprotection from Myocardial Ischemia-Reperfusion Injury by Antagonizing Monocyte-Mediated Inflammation. Sci. Rep. 2016, 6, 29601. [CrossRef] [PubMed]

33. De Araújo, A.A.; Varela, H.; de Castro Brito, G.A.; de Medeiros, C.A.C.X.; de Souza Araújo, L.; do Nascimento, J.H.O.; de Araújo Júnior, R.F. Azilsartan Increases Levels of IL-10, Down-Regulates MMP-2, MMP-9, RANKL/RANK, Cathepsin K and Up-Regulates OPG in an Experimental Periodontitis Model. PLoS ONE 2014, 9, e96750. [CrossRef]

34. Ishii, M.; Kaikita, K.; Sato, K.; Sueta, D.; Fujisue, K.; Arima, Y.; Oimatsu, Y.; Mitsuse, T.; Onoue, Y.; Araki, S.; et al. Cardioprotective Effects of LCZ696 (Sacubitril/Valsartan) After Experimental Acute Myocardial Infarction. JACC Basic Transl. Sci. 2017, 2, 655-668. [CrossRef] [PubMed]

35. Miller, A.B. Aldosterone antagonism in heart failure. Vasc. Health Risk Manag. 2007, 3, 605-609. [PubMed]

36. Mill, J.G.; Milanez, M.D.C.; de Resende, M.M.; Gomes, M.D.G. S.; Leite, C.M. Spironolactone prevents cardiac collagen proliferation after myocardial infarction in rats. Clin. Exp. Pharmacol. Physiol. 2003, 30, 739-744. [CrossRef] [PubMed]

37. National Institute for Health and Care Excellence. Antiplatelet Drugs. 2018. Available online: https: / / bnf.nice.org.uk/treatment-summary / antiplatelet-drugs.html (accessed on 30 October 2018).

38. Gawaz, M. Role of platelets in coronary thrombosis and reperfusion of ischemic myocardium. Cardiovasc. Res. 2004, 61, 498-511. [CrossRef] [PubMed] 
39. National Institute for Health and Care Excellence. Myocardial Infarction: Cardiac Rehabilitation and Prevention of Further Cardiovascular Disease. 2013. Available online: https:/ / www.nice.org.uk/guidance/ cg172 (accessed on 22 October 2018).

40. Fitzpatrick, F.A. Cyclooxygenase enzymes: Regulation and function. Curr. Pharm. Des. 2004, 10, 577-588. [CrossRef] [PubMed]

41. Cattaneo, M. P2Y 12 receptors: Structure and function. J. Thromb. Haemost. 2015, 13, S10-S16. [CrossRef] [PubMed]

42. Fullard, J. The Role of the Platelet Glycoprotein IIb/IIIa in Thrombosis and Haemostasis. Curr. Pharm. Des. 2004, 10, 1567-1576. [CrossRef] [PubMed]

43. Stancu, C.; Sima, A. Statins: Mechanism of action and effects. J. Cell. Mol. Med. 2001, 5, 378-387. [CrossRef] [PubMed]

44. Maron, D.J.; Fazio, S.; Linton, M.F. Current Perspectives on Statins. Circulation 2000, 101, 207-213. [CrossRef] [PubMed]

45. Wolfrum, S.; Jensen, K.S.; Liao, J.K. Endothelium-dependent effects of statins. Arterioscler. Thromb. Vasc. Biol. 2003, 23, 729-736. [CrossRef] [PubMed]

46. Ludman, A.; Venugopal, V.; Yellon, D.M.; Hausenloy, D.J. Statins and cardioprotection-More than just lipid lowering? Pharmacol. Ther. 2009, 122, 30-43. [CrossRef] [PubMed]

47. Soud, M.; Ho, G.; Kuku, K.O.; Hideo-Kajita, A.; Waksman, R.; Garcia-Garcia, H.M. Impact of statins preloading before PCI on periprocedural myocardial infarction among stable angina pectoris patients undergoing percutaneous coronary intervention: A meta-analysis of randomized controlled trials. Cardiovasc. Revasc. Med. 2018. [CrossRef] [PubMed]

48. Pan, Y.; Tan, Y.; Li, B.; Li, X. Efficacy of high-dose rosuvastatin preloading in patients undergoing percutaneous coronary intervention: A meta-analysis of fourteen randomized controlled trials. Lipids Health Dis. 2015, 14, 97. [CrossRef] [PubMed]

49. Sola, S.; Mir, M.Q.S.; Lerakis, S.; Tandon, N.; Khan, B.V. Atorvastatin improves left ventricular systolic function and serum markers of inflammation in nonischemic heart failure. J. Am. Coll. Cardiol. 2006, 47, 332-337. [CrossRef] [PubMed]

50. Davignon, J.; Leiter, L.A. Ongoing clinical trials of the pleiotropic effects of statins. Vasc. Health Risk Manag. 2005, 1, 29-40. [CrossRef] [PubMed]

51. Zacchigna, S.; Martinelli, V.; Moimas, S.; Colliva, A.; Anzini, M.; Nordio, A.; Costa, A.; Rehman, M.; Vodret, S.; Pierro, C.; et al. Paracrine effect of regulatory T cells promotes cardiomyocyte proliferation during pregnancy and after myocardial infarction. Nat. Commun. 2018, 9, 2432. [CrossRef] [PubMed]

52. National Institute for Health and Care Excellence. Beta-Adrenoceptor Blocking Drugs. 2018. Available online: https:/ /bnf.nice.org.uk/treatment-summary/beta-adrenoceptor-blocking-drugs.html (accessed on 30 October 2018).

53. National Institute for Health and Care Excellence. Chronic Heart Failure in Adults: Diagnosis and Management. 2015. Available online: https:/ / www.nice.org.uk/guidance/ng106 (accessed on 30 October 2018).

54. Hunt, S.A.; Abraham, W.T.; Chin, M.H.; Feldman, A.M.; Francis, G.S.; Ganiats, T.G.; Jessup, M.; Konstam, M.A.; Mancini, D.M.; Michl, K.; et al. ACC/AHA 2005 Guideline Update for the Diagnosis and Management of Chronic Heart Failure in the Adult-Summary Article. J. Am. Coll. Cardiol. 2005. [CrossRef]

55. Ong, S.; Rose, N.R.; Čiháková, D. Natural killer cells in inflammatory heart disease. Clin. Immunol. 2017, 175, 26-33. [CrossRef] [PubMed]

56. Varda-Bloom, N.; Leor, J.; Ohad, D.G.; Hasin, Y.; Amar, M.; Fixler, R.; Battler, A.; Eldar, M.; Hasin, D. Cytotoxic T lymphocytes are activated following myocardial infarction and can recognize and kill healthy myocytes in vitro. J. Mol. Cell. Cardiol. 2000, 32, 2141-2149. [CrossRef] [PubMed]

57. Sparks, M.A.; Crowley, S.D.; Gurley, S.B.; Mirotsou, M.; Coffman, T.M. Classical Renin-Angiotensin system in kidney physiology. Compr. Physiol. 2014, 4, 1201-1208. [CrossRef] [PubMed]

58. Bernstein, K.E.; Ong, F.S.; Blackwell, W.-L. B.; Shah, K.H.; Giani, J.F.; Gonzalez-Villalobos, R.A.; Shen, X.Z.; Fuchs, S.; Touyz, R.M. A modern understanding of the traditional and nontraditional biological functions of angiotensin-converting enzyme. Pharmacol. Rev. 2013, 65, 1-46. [CrossRef] [PubMed] 
59. Di Raimondo, D.; Tuttolomondo, A.; Butta, C.; Miceli, S.; Licata, G.; Pinto, A. Effects of ACE-Inhibitors and Angiotensin Receptor Blockers on Inflammation. Curr. Pharm. Des. 2012, 18, 4385-4413. [CrossRef] [PubMed]

60. Leuschner, F.; Panizzi, P.; Chico-Calero, I.; Lee, W.W.; Ueno, T.; Cortez-Retamozo, V.; Waterman, P.; Gorbatov, R.; Marinelli, B.; Iwamoto, Y.; et al. Angiotensin-converting enzyme inhibition prevents the release of monocytes from their splenic reservoir in mice with myocardial infarction. Circ. Res. 2010, 107, 1364-1373. [CrossRef] [PubMed]

61. Soejima, H.; Ogawa, H.; Yasue, H.; Kaikita, K.; Takazoe, K.; Nishiyama, K.; Misumi, K.; Miyamoto, S.; Yoshimura, M.; Kugiyama, K.; et al. Angiotensin-converting enzyme inhibition reduces monocyte chemoattractant protein-1 and tissue factor levels in patients with myocardial infarction. J. Am. Coll. Cardiol. 1999, 34, 983-988. [CrossRef]

62. Robinson, E.A.; Yoshimura, T.; Leonard, E.J.; Tanaka, S.; Griffin, P.R.; Shabanowitz, J.; Hunt, D.F.; Appella, E. Complete amino acid sequence of a human monocyte chemoattractant, a putative mediator of cellular immune reactions. Proc. Natl. Acad. Sci. USA 1989, 86, 1850-1854. [CrossRef] [PubMed]

63. Bavishi, C.; Messerli, F.H.; Kadosh, B.; Ruilope, L.M.; Kario, K. Role of neprilysin inhibitor combinations in hypertension: Insights from hypertension and heart failure trials. Eur. Heart J. 2015, 36, 1967-1973. [CrossRef] [PubMed]

64. National Institute for Health and Care Excellence. Sacubitril Valsartan for Treating Symptomatic Chronic Heart Failure with Reduced Ejection Fraction. 2016. Available online: https:/ / www.nice.org.uk/guidance/ ta388 (accessed on 22 October 2018).

65. McMurray, J.J.V.; Adamopoulos, S.; Anker, S.D.; Auricchio, A.; Böhm, M.; Dickstein, K.; Falk, V.; Filippatos, G.; Fonseca, C.; Gomez-Sanchez, M.A.; et al. ESC Committee for Practice Guidelines ESC Guidelines for the diagnosis and treatment of acute and chronic heart failure 2012: The Task Force for the Diagnosis and Treatment of Acute and Chronic Heart Failure 2012 of the European Society of Cardiology. Developed in collaboration with the Heart Failure Association (HFA) of the ESC. Eur. Heart J. 2012, 33, 1787-1847. [CrossRef] [PubMed]

66. Weber, K.T.; Brilla, C.G. Pathological hypertrophy and cardiac interstitium. Fibrosis and renin-angiotensin-aldosterone system. Circulation 1991, 83, 1849-1865. [CrossRef] [PubMed]

67. Suematsu, Y.; Miura, S.; Goto, M.; Matsuo, Y.; Arimura, T.; Kuwano, T.; Imaizumi, S.; Iwata, A.; Yahiro, E.; Saku, K. LCZ696, an angiotensin receptor-neprilysin inhibitor, improves cardiac function with the attenuation of fibrosis in heart failure with reduced ejection fraction in streptozotocin-induced diabetic mice. Eur. J. Heart Fail. 2016, 18, 386-393. [CrossRef] [PubMed]

68. Bahit, M.C.; Kochar, A.; Granger, C.B. Post-Myocardial Infarction Heart Failure. JACC Heart Fail. 2018, 6, 201-208. [CrossRef] [PubMed]

69. Van Tassell, B.W.; Abouzaki, N.A.; Oddi Erdle, C.; Carbone, S.; Trankle, C.R.; Melchior, R.D.; Turlington, J.S.; Thurber, C.J.; Christopher, S.; Dixon, D.L.; et al. Interleukin-1 Blockade in Acute Decompensated Heart Failure. J. Cardiovasc. Pharmacol. 2016, 67, 544-551. [CrossRef] [PubMed]

70. Ridker, P.M.; Everett, B.M.; Thuren, T.; MacFadyen, J.G.; Chang, W.H.; Ballantyne, C.; Fonseca, F.; Nicolau, J.; Koenig, W.; Anker, S.D.; et al. Antiinflammatory Therapy with Canakinumab for Atherosclerotic Disease. N. Engl. J. Med. 2017, 377, 1119-1131. [CrossRef] [PubMed]

71. Nasiripour, S.; Gholami, K.; Mousavi, S.; Mohagheghi, A.; Radfar, M.; Abdollahi, M.; Khazaeipour, Z.; Mojtahedzadeh, M. Comparison of the Effects of Enoxaparin and Heparin on Inflammatory Biomarkers in Patients with ST-segment Elevated Myocardial Infarction: A prospective Open Label Pilot Clinical Trial. Iran. J. Pharm. Res. IJPR 2014, 13, 583-590. [PubMed]

72. Wollert, K.C.; Drexler, H. The role of interleukin-6 in the failing heart. Heart Fail. Rev. 2001, 6, 95-103. [CrossRef] [PubMed]

73. Stone, G.W. Bivalirudin in acute myocardial infarction: NICE guidance. Heart. 2012, 98, 435-437. [CrossRef] [PubMed]

74. Young, E. The anti-inflammatory effects of heparin and related compounds. Thromb. Res. 2008, 122, 743-752. [CrossRef] [PubMed] 
75. Pizarro, G.; Fernández-Friera, L.; Fuster, V.; Fernández-Jiménez, R.; García-Ruiz, J.M.; García-Álvarez, A.; Mateos, A.; Barreiro, M.V.; Escalera, N.; Rodriguez, M.D.; et al. Long-term benefit of early pre-reperfusion metoprolol administration in patients with acute myocardial infarction: Results from the Metocard-CNIC trial (Effect of Metoprolol in Cardioprotection during an Acute Myocardial Infarction). J. Am. Coll. Cardiol. 2014, 63, 2356-2362. [CrossRef] [PubMed]

76. Guedeney, P.; Vogel, B.; Mehran, R. Non-vitamin K antagonist oral anticoagulant after acute coronary syndrome: Is there a role? Interv. Cardiol. Rev. 2018, 13, 93. [CrossRef]

77. Ivabradine for Treating Chronic Heart Failure. Available online: https://www.nice.org.uk/guidance/ta267 (accessed on 22 October 2018).

78. Rohm, I.; Kretzschmar, D.; Pistulli, R.; Franz, M.; Schulze, P.C.; Stumpf, C.; Yilmaz, A. Impact of Ivabradine on Inflammatory Markers in Chronic Heart Failure. J. Immunol. Res. 2016, 2016, 1-12. [CrossRef] [PubMed]

79. Pistulli, R.; Hammer, N.; Rohm, I.; Kretzschmar, D.; Jung, C.; Figulla, H.-R.; Yilmaz, A. Decrease of circulating myeloid dendritic cells in patients with chronic heart failure. Acta. Cardiol. 2016, 71, 165-172. [CrossRef] [PubMed]

80. Sugi, Y.; Yasukawa, H.; Kai, H.; Fukui, D.; Futamata, N.; Mawatari, K.; Oba, T.; Nagata, N.; Kyougoku, S.; Koga, M.; et al. Reduction and activation of circulating dendritic cells in patients with decompensated heart failure. Int. J. Cardiol. 2011, 147, 258-264. [CrossRef] [PubMed]

81. Dominguez-Rodriguez, A.; Consuegra-Sanchez, L.; Blanco-Palacios, G.; Abreu-Gonzalez, P.; Sanchez-Grande, A.; Bosa-Ojeda, F.; Kaski, J.C. Anti-inflammatory effects of ivabradine in patients with acute coronary syndrome: A pilot study. Int. J. Cardiol. 2012, 158, 160-162. [CrossRef] [PubMed]

82. Traverse, J.H.; Henry, T.D.; Pepine, C.J.; Willerson, J.T.; Chugh, A.R.; Yang, P.C.; Zhao, D.; Ellis, S.G.; Forder, J.R.; Perin, E.C.; et al. The TIME Trial: Effect of Timing of Stem Cell Delivery Following ST-Elevation Myocardial Infarction on the Recovery of Global and Regional Left Ventricular Function. Circ. Res. 2018, 122, 479-488. [CrossRef] [PubMed]

83. D'Amario, D.; Leone, A.M.; Borovac, J.A.; Cannata, F.; Siracusano, A.; Niccoli, G.; Crea, F. Granulocyte colony-stimulating factor for the treatment of cardiovascular diseases: An update with a critical appraisal. Pharmacol. Res. 2018, 127, 67-76. [CrossRef] [PubMed]

84. Bewtra, M.; Lewis, J.D. Update on the risk of lymphoma following immunosuppressive therapy for inflammatory bowel disease. Expert Rev. Clin. Immunol. 2010, 6, 621-631. [CrossRef] [PubMed] 